\title{
Digitalized Simulation Of The Legal Theory Of Space, Evolution Technology Of Legal Science Learning In Database Of Dart Of Information Technology Development
}

\author{
Nugraha Pranadita ${ }^{1}$, Imas Rosidawati Wiradirja ${ }^{2}$, Tansah Rahmatullah ${ }^{3}$ \\ \{nugpra@yahoo.com¹,i_rosida_df@yahoo.co.id ${ }^{2}$, tansbana@gmail.com $\left.{ }^{3}\right\}$ \\ Universitas Islam Nusantara, Jalan Soekarno Hatta Nomor 530 Bandung, Indonesia ${ }^{123}$
}

\begin{abstract}
The development of the theory of space law is an abstraction of ideas so that it becomes a general theory. A collection of essences in their ideal form is constructed by using the framework of existence in reality so as to form the real building of the formula of space laws. The complexity of truth-seeking thought will find its equilibrium when das sollen and das sein are two sides and one common currency. The organic building of men that is formed from a wide variety of perspectives allows different reasoning to a common reality because perspective is a collaborative residue of values and norms within the time frame. It takes an authoritative vehicle to bring syncretism of thought to the ultimate righteousness according to science. Development of information technology in the application of digitalization simulation the theory of space law becomes an inevitability of the evolution of learning technology itself.
\end{abstract}

Keywords: Theory, concept, digitization, and simulation

\section{Introduction}

In 2006 estimated that there were 10 main trends that reshaped the world 20 years from now (in 2026), namely; (1) igniting the future/energy crisis, (2) economic innovation, (3) future labor forces, (4) extending life in medicine, (5) strange science, (6) securing the future / most dangerous threats to our freedom and life, (7) the future of globalization; clash of cultures, (8) the future of climate change, (9) the future individuals, and (10) the future of America and China[1]. Then, there were ten kinds of major industries of the innovation economy which would benefit from the future of the world, namely; (1) pharmaceutical health, (2) energy, (3) manufacturing, (4) communication, (5) transportation, (6) security, (7) entertainment media, (8) education and learning, (9) knowledge engineering, and (10) smart materials.

More specifically, the related to education, learning and or science occupies a portion of $20 \%$ of the industry innovation. The magnitude of the education influence percentage can give us confidence in the future, a period not too far from now, industries related to education will become the main industry in the world.

Education in Indonesia is one of the Mandatory Government Affairs relating to Basic Services. Mandatory government affairs are Government Affairs that must be held by all Regions. Whereas, basic services are public service of citizens' basic needs. Education is also 
a government affair divided between the central government, the provincial government, and district/city government called concurrent government affairs. Every citizen obtained the education at a minimum as one part of the minimum service standard. Intermediate and special level education is the authority of the Provincial Government to handle it. While preschool, basic, and equality education are the authority of the District Government to handle it[2]. Nationally, the budget for the education sector in the APBN (State Budget) is around 20\%. From the total budget of 2,220 trillion rupiahs in the State Budget (APBN) for 2018 Fiscal Year, In Appendix XIX of the Presidential Regulation (Perpres) Number 107 of 2017 concerning the Details of the State Budget (APBN) of the 2018 Budget Year has allocated 444,131 trillion rupiahs for education.

If a comparison of the education system in various countries in the world is carried out, then currently 20 countries that have the best education system are; (1) South Korea, (2) Japan, (3) Singapore, (4) Hong Kong, (5) Finland, (6) United Kingdom, (7) Canada, (8) Netherlands, (9) Ireland, (10) Poland, (11) Denmark, (12) Germany, (13) Russia, (14) United States, (15) Australia, (16) New Zealand, (17) Israel, (18) Belgium, (19) Czech Republic, and (20) Switzerland. Although Indonesia has not been able to sit on the world's best figures or at least in the top 100 in terms of the education system, it certainly cannot dampen the enthusiasm of all components of the nation to continue to develop a good education system and in accordance with the laws and regulations.

The development of science and technology is inseparable from the existence of research activities. The research and innovation budget of Indonesia is 1.7 trillion rupiahs in 2018 DIKTI gets a budget of 40.39 trillion rupiahs from 41,28 trillion rupiahs, then Research and Technology get Rp. 0.89 trillion. Then specifically for the Risbang and Innovation budget, the total budget is 1.7 trillion rupiahs where Risbang is 1.59 trillion rupiahs and Innovation is 145.2 billion rupiahs.

The research budget in Indonesia currently only reaches $0.1 \%$ of GDP (Gross Domestic Product) for each year. Meanwhile ; Malaysia 1.25\%, China 2.0\% Singapore $2.20 \%$, Japan $3.60 \%$, South Korea 4.0\%, and developed countries OECD such as Germany $2.90 \%$, Sweden $3.20 \%$, US $2.75 \%$. About $80 \%$ of the research budget in Indonesia comes from the government budget, while the remaining $20 \%$ comes from industry and the private sector. Different things happen in developed countries, the research budget from the private sector (industry) has reached 75 per cent.

Based on the description above, the real gap between das sollen and das sein that occur in Indonesia is related to the future trends of the world. It is related to economic innovation which is more specific includes education, learning and knowledge engineering described as follows:

In the field of education and learning, the state budget used to carry out education in Indonesia reaches the amount of $20 \%$ of the APBN (State Budget) for each year[3]. With a budget of that size, the expectation of das sollen is the education system in Indonesia will become part of an advanced/good education system in the world. In fact (das sein), the implementation of the education system in Indonesia cannot enter the 100 advanced education systems in the world. While in the field of research (research/development), ideally the research costs of a country are around 2\% of GDP (das sollen), but in reality, the research budget is still around $0.1 \%$ of GDP in Indonesia (das sein). By understanding the condition of das sollen and das sein education / teaching and science / research in Indonesia is related to the title of this research; "Digitizing the Simulation of Space Law Theory, the Evolution of Legal Learning Technology in its Alienation of Information Technology Development", the identification of the problem of this research can be formulated as follows: 
1. How can the learning process of law related to the theory of space law that is carried out by utilizing information technology?

2. How can information technology be used in the process of learning law related to the theory of space law at an affordable cost in terms of research and its implementation?

\section{Research Methods}

The research was legal research with the main objective to find ways how legal theory (space law theory) can be communicated to the public effectively and efficiently by utilizing the existence of information technology. It is important because to be able to understand the theory of space law requires a sense building that can cross space and time. With all its limitations, humans need tools (tools) to help the process of reasoning development. In conducting its research, researchers intended to use existing information technology as a tool to build this reason. For this reason, researchers are conducting literature studies to find out the development of information technology that exists today and to better understand the theory of space law which is still a developed concept (thought). Based on these facts, this legal research used secondary data as the primary legal material. Such research is known as normative/doctrinal legal research or library law research. Both the input and output of normative legal research are data in the form of sentences (narrative) and do not contain numbers. The truth that is produced by a normative legal research is a pragmatic truth where a truth is true if it can be proved that the truth is true.

\section{Discussion}

From time to time we continually endeavour so that the law can be "grounded" so that it is not alienated in social relations and can be part of the life of the community itself. The results of the effort to "ground" the law at this time may not be as we expected. Part of the law is still a part of das sollen, while the other part of the law that has become part of the das sein still places "justice" as a product of economic value, so to get it is a sacrifice that for some people is very large.

When the law has not been entirely groundless, the theory of space law invites us to put the law in place, beyond the limits of the ability of our five senses to understand it literally. As time goes by, the existence of law in space will shift from the das sollen condition to the das sein condition because it has the potential of economic value that can be utilized by the state as an institution of sovereignty for the welfare of its people. The economic value of space itself moves from the position of das sollen to the position of das sein by utilizing the momentum presented by the development of science and high technology and capital capitalization in large numbers.

The inequality in an ability to master science and high technology, as well as sharp capital capitalization between countries in the world related to the utilization of the economic value of space, has become a barrier to access the economic potential of the intended space. The space of immunity against jurisdictions of countries which are literally under it has actually placed space under the control of the owners/authorities of science and high technology and large capital capitalization, namely; individuals, private legal entities, public legal entities, or international organizations. Section 33 subsection (3) of the 1945 Constitution of the Republic of Indonesia, in fact, have not reflected the full state of Indonesia. One part of Indonesia's 
bloodshed that is as large as land and sea, namely airspace and or space territory has not obtained the place (attention) as it should be.

Geographically Indonesia is between two continents (the continents of Asia and Australia) and two oceans (Indian / Indonesian and the Pacific Ocean), thus naturally Indonesia is the way for the traffic of goods and services between two continents and through the two oceans. The territory of Indonesia is just below the equator with a land area of $\pm 2,012,402 \mathrm{Km}^{2}$ and an area of the sea $\pm 5,877,879 \mathrm{Km}^{2}[4]$. The shape of the earth is not perfectly round, more flat at the poles and fatter at the equator. Gravity in the equatorial region keeps the satellite in position. Based on this fact, it is understandable that Indonesia's equator position is the most ideal area for the satellite position. In 2013, more than 1000 active satellites and thousands of tons of space waste covered our planet.

This international legal instrument related to space is known as Corpus JurisSpatialis which consists of five international agreements, namely; (1) Treaty on Principles of Governing Activities in the Exploration and Use of Outer Space, including the Moon and Other Celestial Bodies in 1967 (The Outer Space Treaty), (2) Agreement on the Rescue of Astronauts, the Return of Astronauts and the Return of Objects Launched into Outer Space in 1968 (the Rescue Agreement), (3) Convention on International Liability for Damage Caused by Space Objects, also known as the Space Liability Convention in 1972 (the liability convention), (4) Convention on Registration of Launched Objects into Outer Space in 1975 (the Registration Convention), and (5) The Activities of the Governing States of the Moon and Other Celestial Bodies in 1979 (The Moon treaty).

The existence of Corpus JurisSpatialis is solely intended to minimize the potential for conflicts that occur between nations internationally related to the use of space for certain interests. One of them is as a bridge for man-made satellites that have certain functions. Currently there are various types of launched satellites in the orbit, including satellites of (1) astronomy, (2) communication, (3) earth observers, (4) navigation, (5) spies, (6) power solar, (7) weather, (8) miniature and (9) space stations. In the various types of satellites, there are commercially and some are non-commercially satellites operated in addition to satellites operated in secret for the benefit of certain countries (spy satellites).

In essence, the orbit split into two, namely; (1) geosynchronous orbit and (2) geostationary orbit. A satellite with a geosynchronous orbit will be at a certain point (coordinate) in space at a certain time, while the satellite with a geostationary orbit will remain in its place (coordinate) all the time. The geostationary satellite orbit is just above the equator at Earth $0^{\circ}$ latitude. Thus the geostationary satellite orbit is a limited natural resource so that it has economic value. It is because the geostationary orbit has a certain capacity to be occupied by satellites.

Indonesia is one country that is right on the equator/equator. Indonesia has also used satellites for development purposes since 1976 with the launch of the Palapa satellite on July 8, 1976. Thus it is natural that Indonesia has the right and interest in the space area that is above its territorial area for the benefit of its people's welfare as mandated in the Preamble (Preambule) of the 1945 Constitution by taking into account the interests of the world community as a whole because after all Indonesia is part of the world community as a whole.

Together with other countries in the world that are in the equator, Indonesia seeks to fight for its space rights through the Bogota Declaration in 1976 signed by Indonesia, Colombia, Ecuador, Uganda, Zaire and Congo. The Bogota Declaration basically requires the sovereignty of countries in the equator over the geostationary orbit region. In its development, the Bogota Declaration was followed up with the Quito Declaration in 1982 which essentially contained demands for Preservation Rights and Prior Authorization for countries in the equatorial region. 
On the one hand, Indonesia feels legally interested in utilizing the geostationary orbit region which is above the country's territorial. On the other hand, the use of space for the sake of the welfare of the Indonesian and nation has no regulation in the 1945 Constitution. In other words, it is natural that countries in the world do not recognize Indonesian territorial space jurisdiction that is above the Indonesian territorial because, in the 1945 Constitution which is the highest written law in Indonesia, there is no regulation.

The law theory formatting, constitutions drafting and law implementing, in reality, are three different things. However, there must be a common thread between them, because they are the cause and effect of each other. The formulation of the law theory can establish the law. Because of law, the implementation of the legislation is a necessity. The formulation of the legal theory can establish the law. Because of law, the implementation of the legislation is a necessity. The implementation of laws and regulations in daily lives must revoke a law theory or form a new law theory. In simple terms, we see it as a repetition of the transition of das sollen to a das sein and back to being a das sollen repeatedly and continuously, moving in a better direction. In this case, the second das sollen is better than the first das sollen, as well as the das sein. The next sein who comes next will be better than das sein who comes first.

The learning process related to understanding law theory is very different compared to the learning process related to the understanding of law and the implementation of the legislation. The difference is due to the learning process of understanding a law theory requires more imagination than the other two learning processes. It because the existence of a law theory is outside the limits of the five senses of man to define it.

Compare the essence of the description in the paragraph above with human understanding of the existence of atoms, neutrons and protons that are part of physics. These three things are real in physics, can the five human senses determine them? The third learning process becomes easier by modelling simulated images by a computer using certain software. In other words, the absence of these three things according to the five human senses is transformed by technology into logical reality and becomes the fifth domain of the human senses to understand it.

The use of information technology, especially technology related to three-dimensional (visual) images has a very large contribution as a tool in the world of education to help understanding related things that require the help of imagination to understand it. On the other hand, information technology continues to grow rapidly over time.

Thus, information technology can certainly provide greater assistance in the future for the development of education. For example for most people, smartphone technology today might be considered to be very capable of meeting their daily needs related to the use of the smartphone. In reality, this has not satisfied smartphone technology developers to continue developing the technology. It is not impossible if one or two years later the smartphone will come up with the ability of a hologram to spoil the use of the technology. If mass-produced products (such as smartphones) used hologram technology which is part of information technology, then it is reasonably reasonable to assume that the price of the technology is no longer exclusive anymore. Thus the hologram technology in time is expected to be used in the world of education, especially law education, to be able to help explain a theory related to something that is beyond the reach of the five human senses to observe it, which in this case is the theory of space law.

By using the reflection process, technology applications can be used in the legal learning process related to the theory of space law (which object is in space), so that the five human senses can visualize objects in space become a reality. Information technology that has the ability to do so is currently available in various forms and uses. The biggest challenge of the 
reflection process is the problem of the availability of technology needed, whether it is technology that is really new or utilizing existing technology for new purposes. Both of these have advantages and disadvantages.

Determining the choice of using new technology or recycling technology in the legal learning process related to the theory of space law must consider several variables carefully. Some of these variables are actually contradictory so that these two variables cannot be used effectively and efficiently at the same time. As an example in general, the cost variable will conflict with the quality variable, where the use of high costs generates good quality. Meanwhile, the use of minimal costs will produce a low quality of a product.

The advantages of applying new technology in the process of learning law science related to the theory of the law of space are because it has conformity to the level expected by researchers in this study. Apart from its weaknesses, this requires certainty of time and cost which are certainly not small. Meanwhile, the main advantage of the application of recycling technology is that the technology is already available on the market, only needs a few modifications to the costs of development and implementation which were certainly not too expensive. Meanwhile, the main weakness of this technology is that the level of conformity with the expectations of the researchers in conducting their research may not be optimal.

\section{Conclusion}

The process of law science learning related to space law theory can take place by utilizing information technology in the form of three-dimensional image-based technology that can visualize space law theory as a means to help build an understanding of the law theory better.

Information technology related to three-dimensional images that can describe the law theory of space developed rapidly over time. The use of mass production of a product can significantly reduce the cost of technology. Thus the widespread use of information technology with various small modifications in research needed as an adjustment can significantly reduce the cost of research and its implementation.

Acknowledgments. Master of Law Studies Program Post-Graduate School of Islamic University of Nusantara, Bandung, Indonesia. This research is funded by DIPA Kopertis Region IV West Java Banten, Ministry of Research, Technology and Higher Education, in accordance with Letter of Agreement of Research of Decentralized Grant Research Fiscal Year 2018 Higher Education Research Program of Higher Education Number: 0048-B / LPPM-UIN / II / 2018.

\section{References}

[1] J. Canton, The Extreme Future, The Top Trends That Will Reshape The World in The Next 20 Years, no. August. New York: Plume, 2007.

[2] A. Wijaya, Pendidikan Matematika Realistik; Suatu Alternatif Pendekatan Pembelajaran Matematika. Yogyakarta: Graha Ilmu, 2013.

[3] B. Ismanto, "Funding Policies on Education Reform in Indonesia," in INTERNATIONAL CONFERENCE ON FUNDAMENTALS AND IMPLEMENTATION OF EDUCATION, 2013 , no. 13 , pp. 1-15.

[4] I. Syofyan, R. Jhonerie, and Y. I. Siregar, "APLIKASI SISTEM INFORMASI GEOGRAFIS DALAM PENENTUAN KESESUAIAN KAWASAN KERAMBA JARING TANCAP DAN RUMPUT LAUT DI PERAIRAN PULAU BUNGURAN KABUPATEN NATUNA," $J$. Perikan. dan Kelaut., vol. 15, no. 2, pp. 111-120, 2010. 
